Open Access to Pharmaceutical and Medical Research

(C) 2011-18, publisher and licensee JDDT, This is an Open Access article which permits unrestricted non-commercial use, provided the original work is properly cited

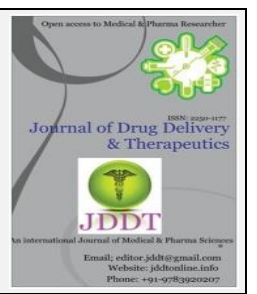

Open $\mathcal{O}_{\text {Access }}$

Research Article

\title{
Phytochemical and Pharmacognostical Studies of Anogeissus acuminata
}

\author{
Vijay Kumar Yadav ${ }^{* 1}$, Raghuveer Irchhiaya ${ }^{2}$ and A. K. Ghosh ${ }^{1}$ \\ ${ }^{1}$ Department of Pharmacy ${ }^{1}$, IFTM University, Moradabad - 244102, Uttar Pradesh, India. \\ 2 Department of Pharmacy ${ }^{2}$, Bundelkhand University, Jhansi - 284128, Uttar Pradesh, India.
}

\begin{abstract}
Medicinal plants are one of the oldest valuable sources of medicine provide by nature to mankind. Medicinal plants are one of the important sources of research of new drugs. Many medicinal plants and herbs hold their prestigious position in the field of natural medicine among which Anogeissus acuminata belonging to family Combretaceae was vital one.

In the present study was intended to evaluate various physicochemical, phytochemical standards like TLC, HPTLC and Pharmacognostic parameters which will be helpful to ensure the purity, safety and efficacy of the medicinal plant.

Anogeissus acuminata was subjected to preliminary phytochemical screening, done to estimate as foreign organic matter, morphological evaluation. Total ash values, physicochemical, Thin layer chromatography (TLC), HPTLC phytochemical analysis and secondary metabolites present in the plant were investigated for the extract.

All physiochemical properties were found within the measureable amount as foreign organic matter less than $1 \% \mathrm{w} / \mathrm{w}$, Total ash values was 12 $\% \mathrm{w} / \mathrm{w}$ with respect to air-dried crude drug. Moisture content was 3.074. Thin layer chromatography (TLC), HPTLC studies were carried for the better isolation and identification of the different components of ethanolic extract. HPTLC carried out in the solvent system - Toluene: Ethyl acetate: Acetic acid (4:3:1). The report of HPTLC indicates the presence of sixteen spots. Preliminary phytochemical analysis confirmed the presence of plant extracts revealed the presence of alkaloids, steroids, terpenoids glycosides, tannins and phenolic compounds.
\end{abstract}

KEYWORDS: TLC, HPTLC, Phytochemical characterization, Anogeissus acuminata

Article Info: Received 03 July 2019; $\quad$ Review Completed 18 Aug 2019; Accepted 23 Aug 2019; Available online 30 Aug 2019

Cite this article as:

Yadav VK, Irchhiaya R, Ghosh AK, Phytochemical and Pharmacognostical Studies of Anogeissus acuminata, Journal of Drug Delivery and Therapeutics. 2019; 9(4-A):450-457 http://dx.doi.org/10.22270/jddt.v9i4-A.3507

*Address for Correspondence:

Vijay Kumar Yadav, Scholar, IFTM University, Moradabad - 244102, Uttar Pradesh, India.

\section{INTRODUCTION:}

The natural products formed within the plants may be nonessential for the survival of plants and their normal physiology, but these secondary metabolites can be of great significance to humans as they may be used in the treatment of many diseases like eczema, dermatitis, skin ulcers and medicines 1 . For quality control of traditional medicines, phytochemical investigations are mainly applied. Now days, secondary plant metabolites with previously unknown pharmacological activities have been extensively investigated as source of medicinal agents. Thus, it makes a great significance to investigate chemical constituents and study pharmacological activity on this plant for its medicinal uses, which will be very useful in the field of medicine as new emerging drug 2 .

Anogeissus acuminata Roxb belongs to the family Combretaceae is popular all over the world for its therapeutic attributes. A. acuminata is widely distributed in south Asia, Arabian Peninsula, Africa and India mainly in the northwest region. The plant contains wide range of bio active constituent like tannin, flavonoids. A. acuminata has been used traditionally to treat various diseases such as headache, menstrual pain, rheumatoid arthritis, tuberculosis, eczema, dermatitis, skin ulcers etc ${ }^{4}$. The leaves and bark have medicinal values and are traditionally used to treat various diseases. A. acuminata is popular all over the world for its medicinal uses in the treatment of many diseases. It has shown promising anti diabetic effect in diabetes mellitus in several studies ${ }^{5}$.The result of methanol extract of the leaves has showed anti- inflammatory and analgesic activity ${ }^{6}$. A. acuminata have been found to possess HIV1- reverse transcriptase inhibitor activity ${ }^{7}$. Aerial parts of the tree are also used for treatment of diabetes mellitus 8 A. acuminata leaves are used in traditional and tribal medicine of Andhra Pradesh to treat painful inflammatory conditions ${ }^{9}$. Hence the present study was aimed to evaluate its scientific validity ${ }^{10}$. Plant image given below in figure 1. 


\subsection{Plant Taxonomy:}

$\begin{array}{lll}\text { Kingdom } & : & \text { Plantae (Plants) } \\ \text { Phylum } & : & \text { Tracheophyta } \\ \text { Class } & : & \text { Magnoliopsida } \\ \text { Order } & : & \text { Myrtales } \\ \text { Family } & : & \text { Combretaceae } \\ \text { Genus } & : & \text { Anogeissus } \\ \text { Species } & : & \text { Anogeissus acuminata }\end{array}$

\section{Vernacular Name:}

The most popular vernacular names available in India as follows:

$\begin{array}{ll}\text { Hindi } & \text { : Dhau, Dhoy and Dhaura } \\ \text { Tamil } & \text { : Nunnera } \\ \text { Malayalam } & \text { : Panchman, Vekkali } \\ \text { Bengali } & \text { : Itchri } \\ \text { Telugu } & \text { : Pasi Chettu, Pedda Manu } \\ \text { Urdu } & \text { : Pasi }\end{array}$

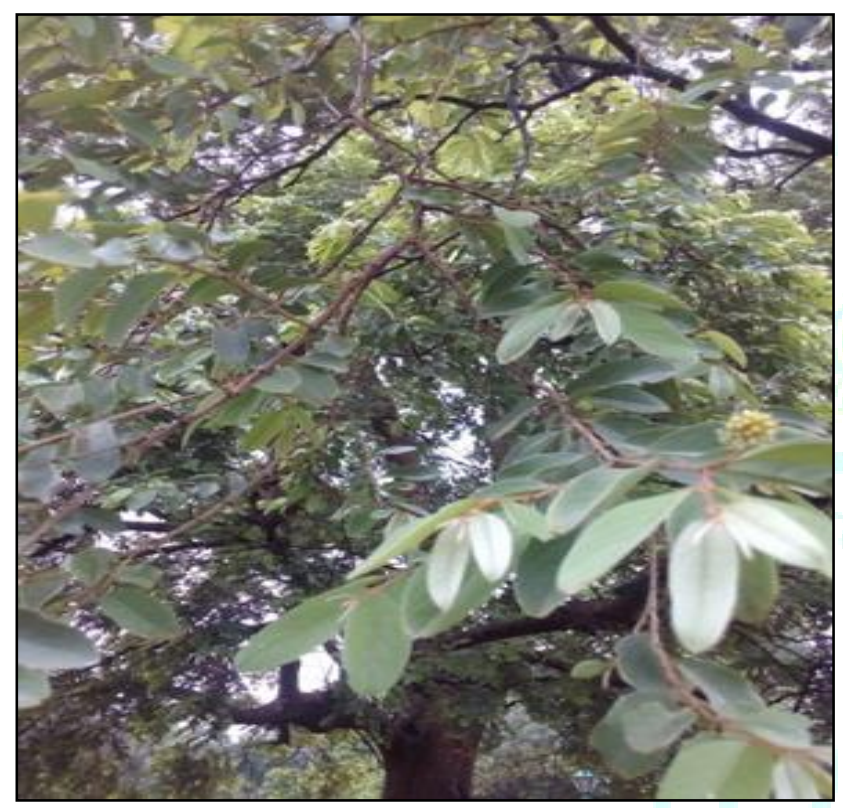

Fig.1: Anogeissus acuminata

\section{MATERIALS AND METHODS:}

2.1 Plant Material: The fresh leaves of Anogeissus acuminata was collected during the month of August 2017 from New Delhi, India. The plant material was identified and authenticated by Dr. Sunita Garg Scientist F and Head, National Institute of Science Communication and Information of Resources (NISCAIR) New Delhi, with reference number NISCAIR/ RHMD/Consult/ 2017/309948.

The fresh leaves of $A$. acuminata were washed, dried under shade and powdered in a mechanical grinder and then passed through sieve no. 40 to get desired particle size and then subjected to physical evaluation and standardization with different parameters.

\subsection{Organoleptic/Morphological Evaluation}

The morphological evaluation means to the studies of external appearance of herbal drugs. Morphological evaluation identifies the degree of purity of crude drugs. The morphological parameters are based on shape, size, colour, surface characteristics, texture and fracture characteristics of drug. Therefore, there is need to identified the identity and determination or check there quality and purity of crude drug. The present study of organoleptic evaluation of crude drug used leaves of $A$. acuminata.

\subsection{Loss on Drying LOD (Gravimetric Determination)}

The determination of Loss on drying which are based on the loss of material after drying and it is determined by LOD techniques. The moisture present in crude drugs may affect the quality of drugs by microbial growth, the presence of fungi or insects, deterioration and also hydrolysis of crude drug to remove the moisture as soon as possible.

The moisture present in crude drugs is not detected by visually therefore; determination of loss on drying of crude drug is required. Here I have taken 5 gm coarse powder of $A$. acuminata and transfer it into a porcelain dish. Then weight of drug the porcelain dish is kept in hot air oven for $2 \mathrm{hrs}$ and maintains the temperature at $100-105{ }^{\circ} \mathrm{C}$. Then, porcelain dish was kept for cooling in dessicator at $30-35^{\circ} \mathrm{C}$ temperature, after cooling then weighed. We have calculated the percentage of Loss on drying with the help of following formula 11 .

$$
\% \text { Loss on Drying }=\frac{\text { Loss in weight of the sample }}{\text { Weight of the sample }} \times 100
$$

\subsection{Determination of Ash Values}

The estimation of ash values of herbal drugs are very important parameter for the determination of quality and purity of herbal drug. In generally the herbal drugs which are available in form of the powder.

The main object of ash values of herbal drugs organized drugs was to remove all traces of organic matter which can otherwise interfere in an estimation analytical determination. On incineration, crude drugs normally leave an ash usually consisting of carbonates, phosphates and silicates of sodium, potassium $\mathrm{Ca}$ and $\mathrm{Mg} 12$.

\subsubsection{Determination of Total Ash Value}

For the determination of total ash value, I have transferred 2 gm of coarse powder of $A$. acuminata in silica crucible. Spread coarse powder in an even layer and ignite it to 500 $600{ }^{\circ} \mathrm{C}$ for $4 \mathrm{hrs}$, until it was white, indicating the absence of carbon. Now silica crucible was cool in a dessicator and weigh. The percentage of total ash value we have calculated as per the reference of the air-dried crude drug with the help of following formula. (Indian Pharmacopoeia, 1996) ${ }^{12}$.

$$
\% \text { Total ash value }=\frac{\text { Weight of total ash }}{\text { Weight of crud drug taken }} \times 100
$$

\subsubsection{Acid Insoluble Ash}

The total ash obtained as above was cover with a watchglass boiled gently with $25 \mathrm{ml}$ of hydrochloric acid for $5 \mathrm{~min}$, Rinse the watch-glass with $5 \mathrm{ml}$ of hot water and add this liquid to the crucible. The insoluble matter was collected in an ash less filter-paper and wash with hot water until the filtrate is neutral.

Transfer the filter-paper containing the insoluble matter to the original crucible, dry on a hotplate and ignite to constant weight. Allow the residue to cool in a suitable dessicator for 30 minutes and then weigh without delay. Calculate the content of acid-insoluble ash in mg per $\mathrm{g}$ of air-dried material.

$\%$ Acid insoluble ash value $=\frac{\text { Wt. of acid insoluble ash }}{\text { Weight of crud drug taken }} \times 100$ 


\subsubsection{Water Soluble Ash}

To the crucible containing the total ash, add $25 \mathrm{ml}$ of water and boil for 5 minutes. Collect the insoluble matter in a sintered-glass crucible. Wash with hot water and ignite in a crucible for 15 minutes at a temperature not exceeding 450 ${ }^{\circ} \mathrm{C}$. Subtract the weight of this residue in $\mathrm{mg}$ from the weight of total ash. I have calculated the content of water-soluble ash in mg per $\mathrm{g}$ of air-dried material.

$\%$ Water soluble ash value $=\frac{\text { Wt. of total ash }- \text { Wt. of water insoluble ash }}{\text { Wt. of crude drug taken }} \times 100$

\subsection{Determination of Foreign Organic Matter}

The main object of the foreign matter of herbal drugs or organized drugs was to avoid contamination. During the storage of natural drugs should special care to avoid formation of moulds, since they may produce aflatoxins. The natural drug should be store in a clean and hygienic place. The natural drugs should be free from any soil, stones, sand, dust and other foreign inorganic matter. The foreign inorganic matter must be removed before drugs powdered in a mechanical grinder.

The foreign matter of the leaves of $A$. acuminata was detected by inspection with the use of a lens $(6 \mathrm{X})$. About $100 \mathrm{~g}$ of the leaves of $A$. acuminata sample were weighed, and spread on paper and removed foreign matter of herbal drugs. It was then separated and weighed the percentage of foreign organic matter was calculated 13 .

\subsection{Preparation of Extract}

In the present study, the shade dried leaves of $A$. acuminata was prepared to coarse powder, 50 gm of powder was taken for extraction. The extraction was carried out in a soxhlet apparatus for $10 \mathrm{~h}$ using petroleum ether $\left(40-60{ }^{\circ} \mathrm{C}\right)$ and ethanol (95\%). The extraction was continued until the solvent in the thimble became clear. After the effective extraction, the solvent was concentrating on water bath using rotary evaporator and the extract obtained with each solvent was weighed. The colour and consistency of the extract was noted, percentage was calculated and stored in dessicator. The results were recorded in Table $1{ }^{14}$.

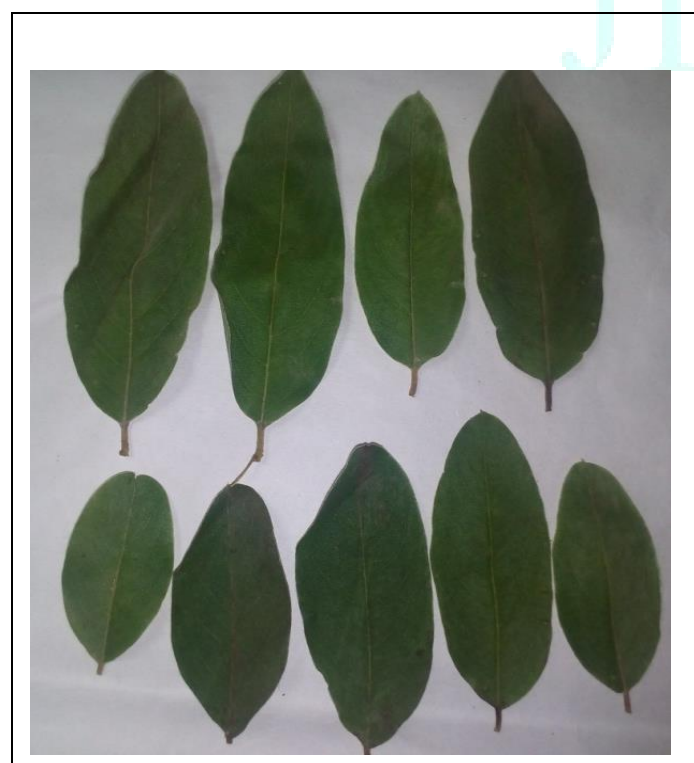

Fig 2-a: Anogeissus acuminata Leaves.

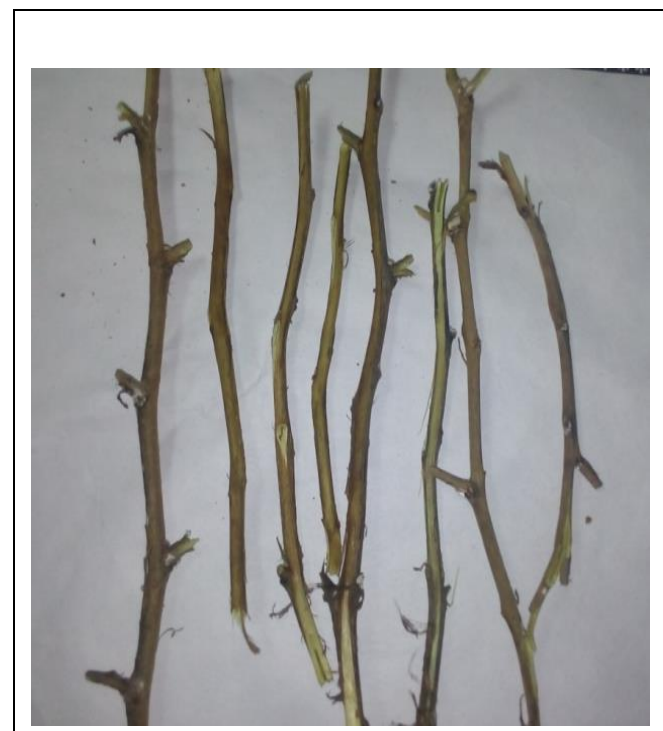

Fig 2-b: Anogeissus acuminata stem

\subsection{Phytochemical Screening}

The phytochemical screening was performed crude extract (Petroleum ether and ethanolic extract) of $A$. acuminata. These obtained extracts were subjected to chemical investigation. About 1 gram of ethanol extract of $A$. acuminata was dissolved in $100 \mathrm{ml}$ of ethanol and was subjected to preliminary phytochemical screenings for determining nature of phytoconstituents present.

Photochemical tests were done in plant extracts for the detection of presence of different secondary plant metabolites and other substances which are responsible for the biological activity. The qualitative results were expressed as (+) for the presence and (-) for the absence of phytochemical for the detection of different chemical constituents were observed 15,16 .

\subsection{Thin Layer Chromatography (TLC)}

Thin Layer Chromatography is the method mainly uses to investigate the presence of chemical constituent which are obtained from plant extracts like saponin, alkaloids, glycosides, carbohydrates, triterpenoids and flavones etc. This component can also run with standards for the investigation. The ethanolic extract of A.acuminata was subjected to thin layer chromatography studies, to find the presence of number of compounds which support by the chemical test. For the investigation of active constituents which are present in A.acuminata ethanolic extract. Thin layer chromatography study of $A$. acuminata was performed in solvent system like, Toluene: Ethyl acetate: Acetic acid (4:3:1). TLC is an easy, versatile and reliable method to establish authenticity, identity and purity ${ }^{17}$.

$R_{f}=\frac{\text { Distance travelled by solute from the origin line }}{\text { Distance travelled by the solvent from the origin line }}$

Where $\mathrm{R}_{\mathrm{f}}=$ Retention factor

\subsubsection{Detail of Thin layer chromatography}

Absorbent: Silica gel

Plate Thickness: $0.4 \mathrm{~mm}$

Size of Plate: $2.5 \times 10 \mathrm{~cm}$

Activation of Temp: $110^{\circ} \mathrm{C}$ for $15 \mathrm{~min}$. 
Volume of Spot: $\quad 20 \mu \mathrm{l}$

Solvent system: Toluene: Ethyl acetate: Acetic acid

(04:03:01).

\subsection{High Performance Thin Layer Chromatography (HPTLC):}

Standardized manufacturing procedures and suitable analytical tools are required to establish the necessary framework for quality control in herbals. HPTLC and capillary electrophoresis are the most widely used to establish reference fingerprints of herbs, against which raw materials can be evaluated and finished products, can be assayed. ${ }^{17}$

High Performance Thin Layer Chromatography also known under the synonym planar chromatography which is a modern, powerful analytical technique with is separation power and reproducibility superior to TLC

\section{HPTLC Parameter:}

Sample preparation: $10 \mathrm{mg} / \mathrm{ml}$

Sample application: Linomat 5 applicator (Camag)

Volume applied: $10 \mu \mathrm{l}$.

Solvent system: Toluene: Ethyl acetate: Acetic acid (04:03:01).

TLC plate development: Presaturated Camag Twin Trough Chamber.

\section{RESULTS}

The evaluation of crude drug means the determination and confirmation of its identity and checks its quality and purity and observed the nature of adulteration. Herbal materials are categorized according to sensory, macroscopic and microscopic characteristics. An examination to determine these characteristics is the first step towards establishing the identity and the degree of purity of such materials, and should be carried out before any further tests are undertaken. The present study of morphological evaluation of crude drug used leaves of $A$. acuminata. The results of macroscopic characteristics were shown in Table 1 and (Fig 1)

\subsection{Loss on Drying (LOD)}

Loss on drying of crude drug an excess of water in herbal materials will encourage microbial growth, the presence of fungi or insects, and deterioration following hydrolysis. Limits for water content should therefore be set for every given herbal material. This is especially important for materials that absorb moisture easily or deteriorate quickly in the presence of water. We have calculated the percentage of loss on drying of drug A. acuminata was found to be 3.74 .

\subsection{Estimation of Ash Values}

The ash remaining following ignition of herbal materials is determined by three different methods which measure total ash, acid-insoluble ash and water-soluble ash. We have calculated of total ash value of $A$. acuminata. Total ash value of $A$. acuminata was found to be $12.2 \mathrm{w} / \mathrm{w}$ with respect to air-dried drug. The results were recorded in Table 1.

The percentage of acid insoluble ash was calculated. Total acid insoluble ash values of $A$. acuminata were found to be 0.780 and $\mathrm{w} / \mathrm{w}$ with respect to air-dried crude drug. The results were recorded in Table 1.

The percentage of water-soluble ash was calculated with reference to the air-dried drug. Water soluble ash of $A$ acuminata was found to be $6.857 \% \mathrm{w} / \mathrm{w}$ respectively, with respect to air-dried crude drug. The results were recorded in Table 1.

\subsection{Determination of Foreign Organic Matter}

Herbal materials should be entirely free from visible signs of contamination by moulds or insects, and other animal contamination, including animal excreta. Foreign organic matter of crude drug was found to be less than $1 \% \mathrm{w} / \mathrm{w}$. The results were recorded in Table 1.

The extraction means the separation of chemical constituents from plants sources.

\subsection{Phytochemical Screening:}

The phytochemical screening was performed crude extract of (petroleum ether and ethanolic extract) of $A$. acuminata. Both extracts of samples of revealed the presence of some secondary metabolites such as alkaloids, steroids and cardiac glycosides as shown in the Table 2 given below respectively. The qualitative results are expressed as (+) for the presence and (-) for the absence of phytochemical for the detection of different chemical constituents are observed in Table 2.

\subsection{Thin Layer Chromatography (TLC)}

Thin-layer chromatography is particularly valuable for the qualitative determination of small amounts of constituents. Thin-layer chromatography is effective and easy to perform, and the equipment required is inexpensive, the technique is frequently used for evaluating herbal materials and their preparations. Thin layer chromatography study of $A$. acuminata was performed in different solvent system. Toluene: Ethyl acetate: Acetic acid (4:3:1).Visualizing agent is vanillin and Iodine.

\subsection{High Performance Thin Layer Chromatography (HPTLC)}

HPTLC studies were carried for the better isolation and Identification of the different components of ethanolic extract of $A$. acuminata. The report of HPTLC indicates the presence of sixteen spots in the solvent system - Toluene: Ethyl acetate: Acetic acid (4:3:1) carried out at NBRI, Lucknow. These HPTLC spots with $\mathrm{R}_{\mathrm{f}}$ value and colour are given below in Table 4, and HPTLC plate as Figure 3 is given respectively.

Table 1: Physico-chemical parameters of Anogeissus acuminata

\begin{tabular}{|l|l|c|}
\hline S.No. & Parameters & Powder (\%w/w) \\
\hline 1 & Foreign organic matter & $0.16 \%$ \\
\hline 2 & Moisture content (LOD) & 3.74. \\
\hline \multicolumn{2}{|l|}{ Ash Values } & 12.2 \\
\hline 3. & Total ash & 2.70 \\
\hline 4. & Acid insoluble ash & 2.32 \\
\hline 5. & Water soluble ash & \\
\hline
\end{tabular}


Table 2: Phytochemical Analysis of Anogeissus acuminata

\begin{tabular}{|c|c|c|c|c|}
\hline $\begin{array}{l}\text { SR. } \\
\text { NO. }\end{array}$ & Chemical Test & $\begin{array}{l}\text { Aqueous } \\
\text { Extract }\end{array}$ & $\begin{array}{l}\text { Petroleum ether } \\
\text { Extract }\end{array}$ & $\begin{array}{l}\text { Ethanolic } \\
\text { Extract }\end{array}$ \\
\hline \multirow[t]{4}{*}{1.} & Test for Alkaloids & & & \\
\hline & Mayer's reagent & _ & + & + \\
\hline & b) Dragendorff's reagent & - & _ & + \\
\hline & c) Wagner reagent & - & - & + \\
\hline \multirow[t]{3}{*}{2.} & Test for Carbohydrates & & & \\
\hline & a) Molisch's test & - & - & _ \\
\hline & Fehling's Test & 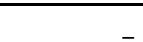 & - & - \\
\hline \multirow[t]{4}{*}{3.} & Test for Glycosides & & & \\
\hline & a) Keller Killaini Test & - & _ & + \\
\hline & b) Baljet's Test & 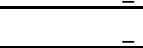 & - & _- \\
\hline & C) Legal's test & & & + \\
\hline \multirow[t]{4}{*}{4.} & Test for Tannins & & & \\
\hline & a) Ferric chloride test & & + & + \\
\hline & b) Lead acetate test & - & _- & + \\
\hline & c) Gelatin test & - & - & - \\
\hline \multirow[t]{3}{*}{5.} & Test for flavonoids & & & \\
\hline & a) Shinoda test & _ & + & + \\
\hline & b) Lead acetate test & _- & _ & + \\
\hline \multirow[t]{4}{*}{6.} & Test for Proteins & & & \\
\hline & a) Million's test & & - & _ \\
\hline & b) Ninhydrin test & & - & \\
\hline & c) Biuret test & & - & _ \\
\hline \multirow[t]{2}{*}{7.} & Test for Amino Acids & & & \\
\hline & a)Ninhydrin test & _ & _ & _ \\
\hline \multirow[t]{3}{*}{8.} & Test for Sterols & & & \\
\hline & a) Salkowaski test & - & - & + \\
\hline & b)Liebermann Burchard test & & & + \\
\hline \multirow[t]{3}{*}{9.} & Test for Triterpene & & & \\
\hline & a) Salkowaski test & & ++ & \\
\hline & b)Liebermann Burchard test & & & \\
\hline \multirow[t]{3}{*}{9.} & Test for Fats and Oils & 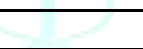 & & \\
\hline & Solubility test & + & + & \\
\hline & Filter paper test & & & \\
\hline
\end{tabular}

Table 3: HPTLC of ethanolic extract of Anogeissus acuminata

\begin{tabular}{|c|c|c|c|c|c|c|c|c|c|c|}
\hline Peak & $\begin{array}{c}\text { Start } \\
\text { Position }\end{array}$ & $\begin{array}{c}\text { Start } \\
\text { Height }\end{array}$ & $\begin{array}{c}\text { Max } \\
\text { Position }\end{array}$ & $\begin{array}{c}\text { Max } \\
\text { Height }\end{array}$ & Max \% & $\begin{array}{c}\text { End } \\
\text { Position } \\
\end{array}$ & $\begin{array}{c}\text { End } \\
\text { Height }\end{array}$ & Area & Area \% & $\begin{array}{c}\text { Assigned } \\
\text { substance }\end{array}$ \\
\hline 1. & 0.00Rf & 194.4AU & 0.01Rf & 318.0AU & $18.14 \%$ & 0.02Rf & $2.2 \mathrm{AU}$ & 2427.1AU & $5.37 \%$ & Unknown \\
\hline 2. & 0.02Rf & $7.7 \mathrm{AU}$ & 0.03Rf & 50.6AU & $2.89 \%$ & 0.04Rf & 30.2AU & 525.0AU & $1.16 \%$ & Unknown \\
\hline 3. & 0.04Rf & 32.3AU & 0.06Rf & 41.5AU & $2.37 \%$ & 0.08Rf & $0.3 A U$ & 705.1AU & $1.56 \%$ & Unknown \\
\hline 4. & 0.35Rf & 41.2AU & 0.43Rf & 91.0AU & $7.54 \%$ & $0.46 R f$ & 29.0AU & 8439.6AU & $18.66 \%$ & Unknown \\
\hline 5. & $0.47 \mathrm{Rf}$ & 30.9AU & 0.50Rf & 132.1AU & $3.17 \%$ & $0.50 \mathrm{Rf}$ & 49.2AU & 1284.3AU & $2.84 \%$ & Unknown \\
\hline 6. & 0.51Rf & 48.6AU & 0.53Rf & 62.8AU & $3.58 \%$ & 0.55Rf & 53.6AU & 2367.9AU & $5.23 \%$ & Unknown \\
\hline 7. & 0.56Rf & 52.3AU & 0.58Rf & 63.1AU & $3.60 \%$ & 0.59Rf & 56.0AU & 1309.9AU & $2.90 \%$ & Unknown \\
\hline 8. & 0.59Rf & $56.2 \mathrm{AU}$ & 0.59 Rf & 60.7AU & $3.46 \%$ & 0.60Rf & 48.6AU & 661.1AU & $1.46 \%$ & Unknown \\
\hline 9. & $0.60 \mathrm{Rf}$ & 49.4AU & $0.60 \mathrm{Rf}$ & 53.1AU & $3.03 \%$ & 0.62Rf & 30.6AU & 799.4AU & $1.77 \%$ & Unknown \\
\hline 10. & $0.64 \mathrm{Rf}$ & 35.2AU & 0.66Rf & 83.5AU & $4.67 \%$ & 0.68Rf & 36.5AU & 2748.7AU & $6.08 \%$ & Unknown \\
\hline 11. & 0.70Rf & 72.2AU & 0.73Rf & 204.4AU & $11.66 \%$ & 0.76Rf & 33.3AU & 5786.3AU & $12.79 \%$ & Unknown \\
\hline 12. & 0.76Rf & 63.4AU & 0.79Rf & 94.8AU & $5.41 \%$ & 0.80Rf & 35.5AU & 2815.3AU & $6.22 \%$ & Unknown \\
\hline 13. & 0.80Rf & 86.5AU & 0.82Rf & 193.7AU & $11.05 \%$ & 0.83Rf & 48.2AU & 5167.0AU & $11.42 \%$ & Unknown \\
\hline 14. & $0.84 R f$ & 148.8AU & $0.85 R f$ & 189.7AU & $10.82 \%$ & 0.87Rf & 34.1AU & 5072.7AU & $11.21 \%$ & Unknown \\
\hline 15. & $0.87 \mathrm{Rf}$ & $94.2 \mathrm{AU}$ & $0.89 \mathrm{Rf}$ & 112.2AU & $6.4 \%$ & $0.94 \mathrm{Rf}$ & $34.3 \mathrm{AU}$ & 4222.9AU & $9.33 \%$ & Unknown \\
\hline 16. & $0.94 \mathrm{Rf}$ & $34.5 \mathrm{AU}$ & $0.95 \mathrm{Rf}$ & $36.9 \mathrm{AU}$ & $2.11 \%$ & 0.98Rf & 0.1AU & 905.2AU & $2.00 \%$ & Unknown \\
\hline
\end{tabular}




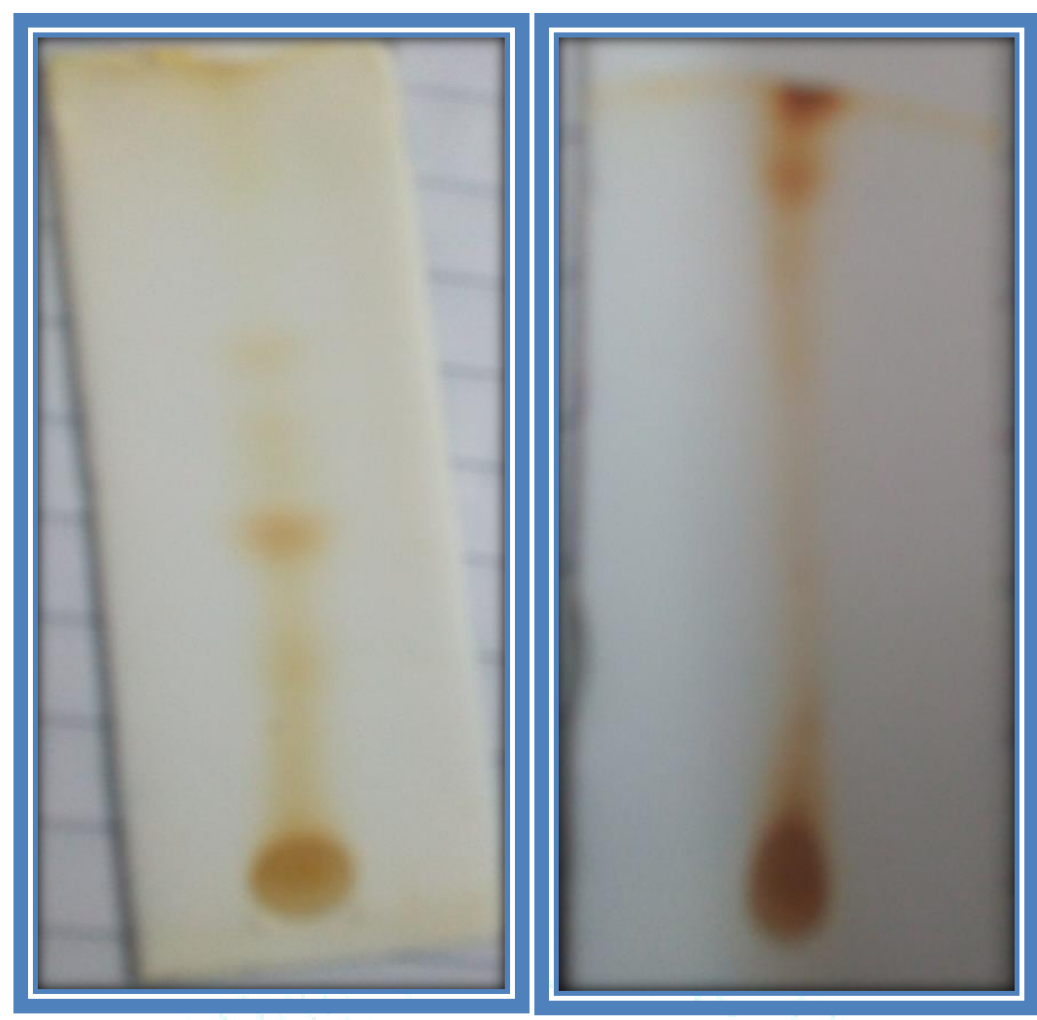

Fig 3: TLC Chromatogram of Anogeissus acuminata

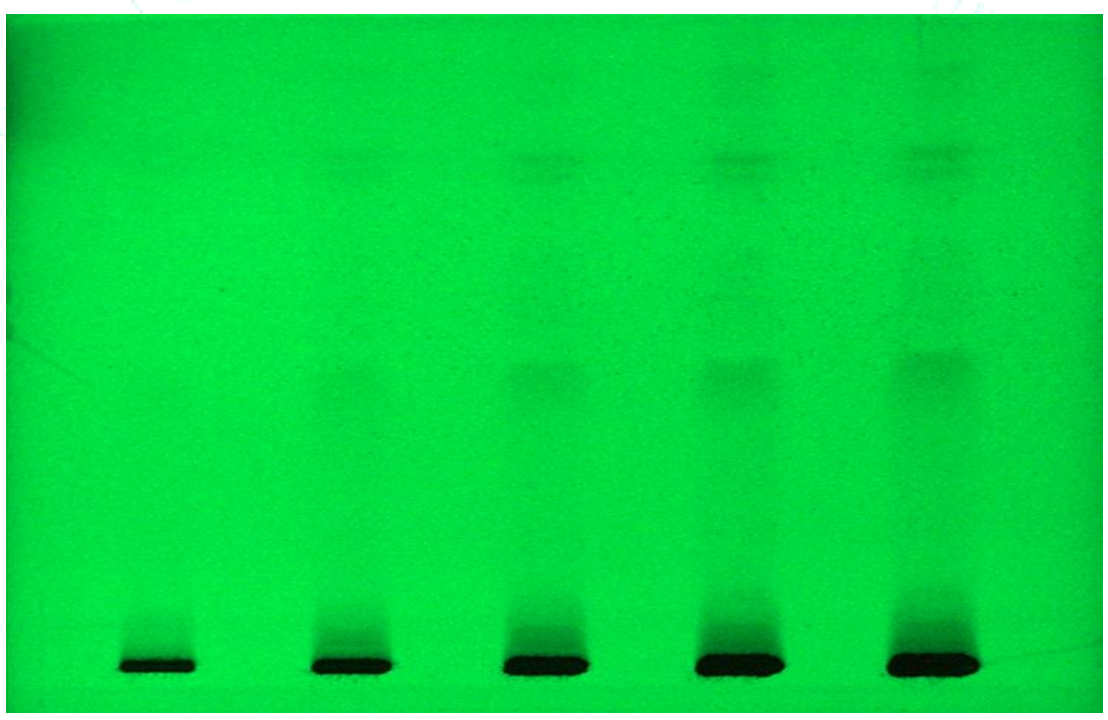

Figure 4: High Performance Thin Layer Chromatography of ethanolic extract of Anogeissus acuminata

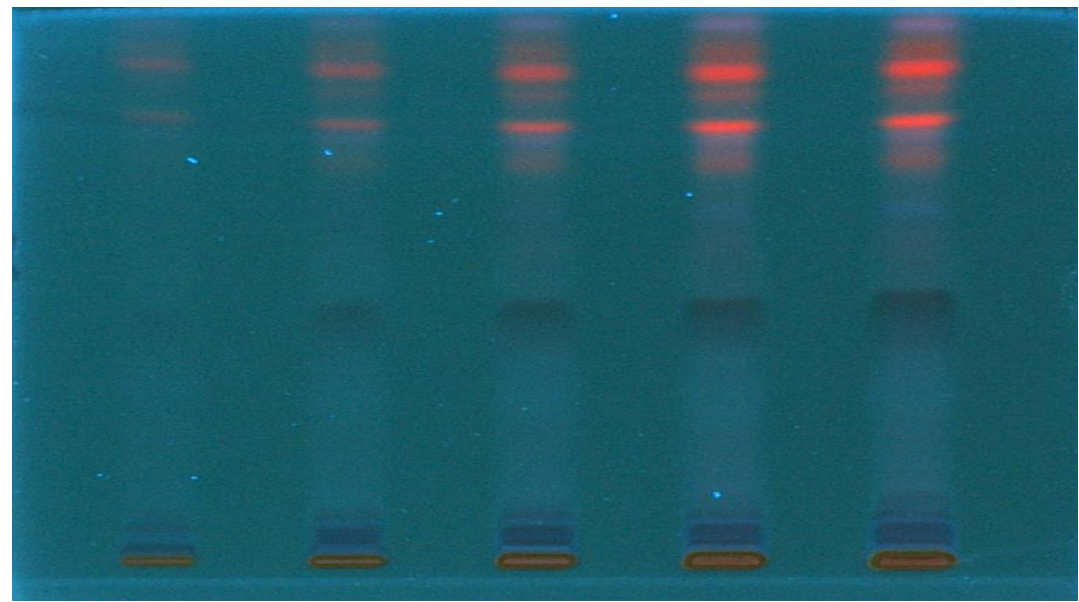

Figure 5: High Performance Thin Layer Chromatography of ethanolic extract of Anogeissus acuminata 


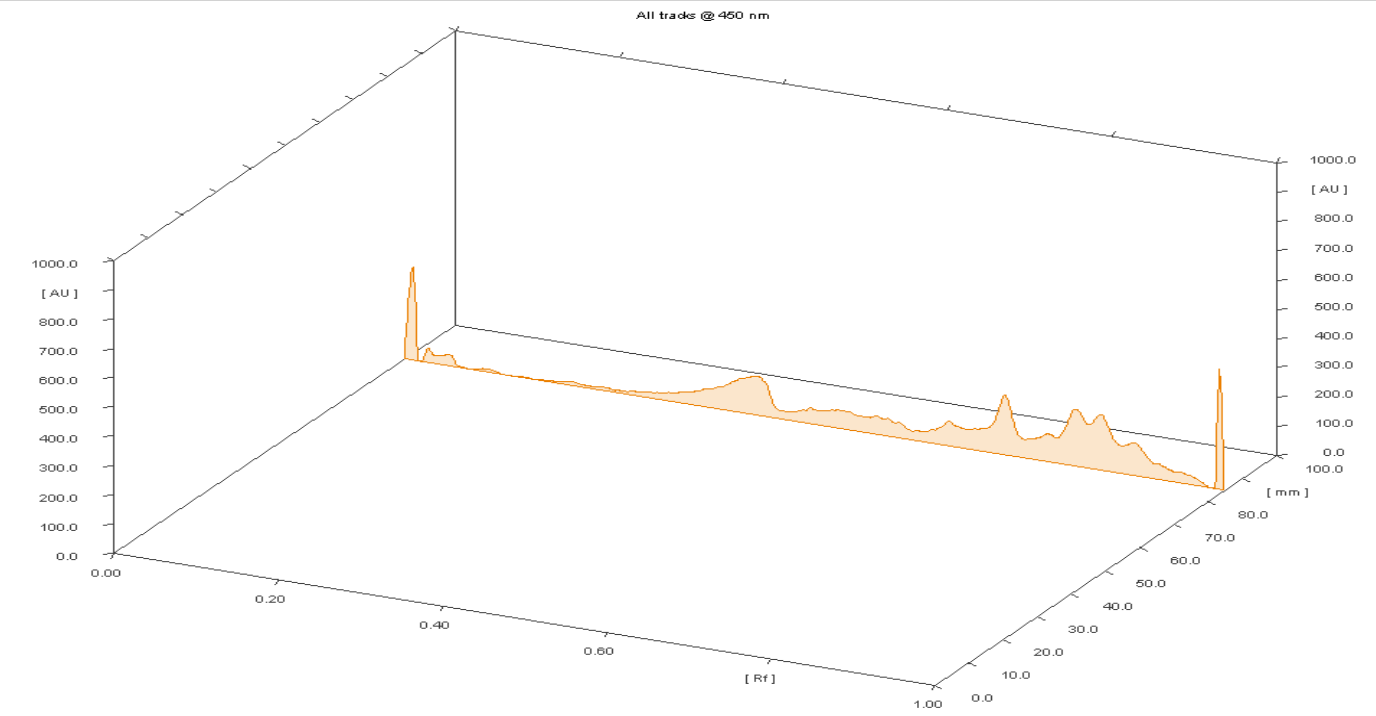

Figure 6: High Performance Thin Layer Chromatography finger printing of ethanolic extract of Anogeissus acuminata

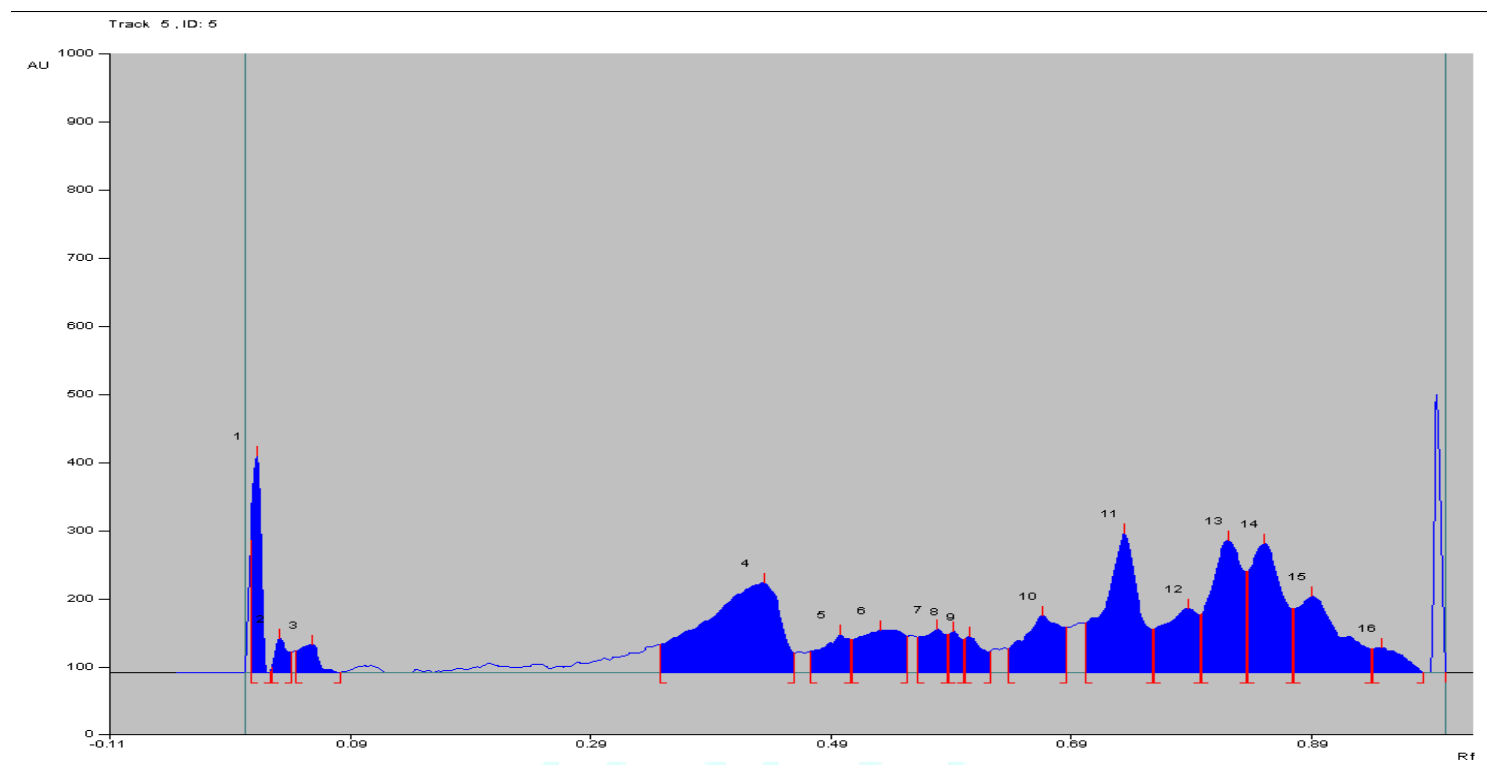

Figure 7: High Performance Thin Layer Chromatography finger printing of ethanolic extract of Anogeissus acuminata

\section{DISCUSSION}

Plants are producing many bioactive chemicals. It can be concluded that the from above the study results of $A$. acuminata can serve as a valuable resource of pharmacognostic and phytochemical information. The above study that its medicinal properties might be due to the presence of some phenolic flavonoids compounds and the phytochemical screening revealed the presence of alkaloids, carbohydrates, flavonoids, glycosides, saponin and steroids other phytochemical present in this plant.

ACKNOWLEDGEMENT: We are grateful to Dr. Raghuveer Irchhiaya, Institute of Pharmacy, Bundelkhand University, Jhansi for his assistance and encouragement. We extend our sincere thanks to Professor A.K. Ghosh IFTM University, Moradabad for critically reading the Manuscript and providing the valuable suggestions.

CONFLICTS OF INTEREST: There are no conflicts of interest.

\section{REFERENCES:}

1. Cowan MM. Plant products as antimicrobial agents. Clin Microbiol Rev. 1999; 12:564-582.

2. Yadav VK, Singh AK, Chaudhari VK, Verma, Singh AK, Rajpoot S: TLC, HPTLC Studies and qualitative Phytochemical investigations of seeds of Celastrus paniculata Willd. Asian J of Pharmaceutical Technology \& Innovation 2014; 2: 7-14.

3. "Anonymous" The Wealth of India Raw Materials CSIR New Delhi, 1950; 59: 296.

4. Shwetha R, Hemamalin $\mathrm{K}$, Sumalatha $\mathrm{P}$ and Vasireddy U: Antinociceptive Screening of Methanol Extract of Anogeissus Acuminata Research Journal of Pharmaceutical, Biological and Chemical Sciences. 2013; 4(2): 238.

5. Hemamalini K Ramu A., Mallu G., Venkata Srividya V., Sravani V., Deepak P. and Uma Vasi Reddy Evaluation of wound healing activity of different crude extracts of Anogeissus acuminata and Gymnosporia emerginata Rasayan J Chem. 2011; 4 (2) :466-471

6. Hemamalini K, Om Prasad Naik K, and Ashok P: Anti inflammatory and analgesic effect of methanolic extract of Anogeissus acuminata leaf. Int J Pharm Biomed Res. 2010; 1(3): 98-101.

7. Manosroi J, Moses ZZ, Manosroi W and Manosroi A: Hypoglycemic activity of Thai medicinal plants selected from 
the Thai/Lanna medicinal recipe database Manosroi II. J Ethnopharmacol 2011; 138: 92-8.

8. Rimando AM, Pezzuto JM, Farnsworth NR, Santisuk T, Reutrakul V and Kawanishi K: New lignans from Anogeissus acuminata with HIV-1 reverse transcriptase inhibitory activity. J Nat Prod 1994; 57(7): 896-904.

9. Navale AM, Patel KS and Paranjape AN: Phytochemical screening and HPTLC fingerprinting of Anogeissus acuminata extracts. Int. J. Res. Ayurveda Pharm. 2016; 7(S2): 207-209.

10. Zaruwa MZ, Manosroi J, Akihisa $\mathrm{T}$ and Manosroi A: Castalagin from Anogeissus acuminata (Roxb. ex. DC) Guill. Ex. Perr, a potent hypoglycaemic agent. International Journal of Current Research and Academic Review. 2015; 3(7): 147-52.

11. Kokate CK: 'Practical Pharmacognosy' Vallabh Prakashan, $2^{\text {nd }}$ Edition, 1988; 56-68.
12. Indian Pharmacopoeia, Government of India, Ministry of Health and Welfare, Controller of publication, Delhi, 1966; 708.

13. Evans WC: Trease and Evans: Pharmacognosy. $15^{\text {th }}$ ed London: Harcourt Publisher Limited; 2002; 313, 513-25, 53847.

14. Khandelwal KR: Practical Pharmacognosy. $19^{\text {th }}$ ed Pune: Nirali Prakashan; 2008; 149-56, 157-9.

15. Ansari SH: Essentials of Pharmacognosy. $1^{\text {st }}$ ed. New Delhi: Birla Publications Pvt., Ltd.; 2006

16. World Health Organization, Quality Control methods for medicinal plant materials, Geneva, (1998).

17. Chatwal Gurdeep R, Anand Sham K. Instrumental methods of chemical analysis, Himalaya publishing house 2004: (1): 599616 